\title{
Past and present of allspice (Pimenta dioica) in Mexico and Guatemala
}

From traditional management to current large-scale markets

Passé et présent du piment de Jamaïque (Pimenta dioica) au Mexique et au Guatemala: des pratiques traditionnelles aux marchés à grande échelle Pasado y presente de la pimienta de Tabasco (Pimenta dioica) en México y Guatemala: del manejo tradicional a los mercados a gran escala

\section{Paulina Machuca, María Teresa Pulido-Salas and Felipe Trabanino}

\section{(2penEdition}

\section{Journals}

Electronic version

URL: http://journals.openedition.org/ethnoecologie/6261

DOI: $10.4000 /$ ethnoecologie.6261

ISSN: 2267-2419

\section{Publisher}

Laboratoire Eco-anthropologie et Ethnobiologie

\section{Electronic reference}

Paulina Machuca, María Teresa Pulido-Salas and Felipe Trabanino, "Past and present of allspice (Pimenta dioica) in Mexico and Guatemala", Revue d'ethnoécologie [Online], 18 | 2020, Online since 14 December 2020, connection on 29 January 2021. URL: http://journals.openedition.org/ethnoecologie/ 6261 ; DOI: https://doi.org/10.4000/ethnoecologie.6261

This text was automatically generated on 29 January 2021.

\section{c) (†)}

Revue d'ethnoécologie est mis à disposition selon les termes de la licence Creative Commons Attribution - Pas d'Utilisation Commerciale - Pas de Modification 4.0 International. 


\title{
Past and present of allspice (Pimenta dioica) in Mexico and Guatemala
}

\author{
From traditional management to current large-scale markets \\ Passé et présent du piment de Jamaïque (Pimenta dioica) au Mexique et au \\ Guatemala: des pratiques traditionnelles aux marchés à grande échelle \\ Pasado y presente de la pimienta de Tabasco (Pimenta dioica) en México y \\ Guatemala: del manejo tradicional a los mercados a gran escala
}

Paulina Machuca, María Teresa Pulido-Salas and Felipe Trabanino

\section{INTRODUCTION}

1 Many useful plant species widely used in Mesoamerica prior to European contact in the 16th Century were gradually overshadowed by old World plants. These introduced species benefited from the cultural prestige attributed them by the dominant social group, thus marginalizing myriad native species (León 1992). Allspice, Pimenta dioica (L.) Merrill, had medicinal uses among the native peoples of Mesoamerica but the Spanish realized its culinary potential soon after they began colonizing the region. Known variously in Spanish as "Pimienta gorda," "Pimienta Tabasco" and "Malagueta" (Martínez-Pérez et al. 2013), it is native to Mexico and Central America (Bailey 1951), called Mesoamerica, which for floristic purposes encompasses the states of Tabasco, Chiapas, Campeche, Quintana Roo and Yucatan in Mexico, and the Central American countries of Belize, Guatemala, Honduras, El Salvador, Nicaragua, Costa Rica, and Panama (Davidse et al. 2011). In Petén, Guatemala, this species has been an important tree to develop home gardens, where the local people utilize existing trees and leave the most useful (Gillespie et al. 1993). In some places of the Sierra Norte of Puebla (Mexico), most of its production comes from collection in indigenous communities; however, there is a tendency to advance towards its domestication for large-scale commercial purposes (Macía 1998). 
With the aims of a better understanding about the historical changes and confusions of its popular nomenclature, as well as the uses and management as a natural resource, we provide a historical panorama of allspice's trajectory beginning in the 16th Century. We also address the logic behind the trade routes during the Spanish Viceroyalty and the factors that prevailed over five centuries, bringing it both regional and worldwide prominence. Additionally, we integrate concepts from sustainability science, which focuses on understanding the interactions between nature and society and analyzes sustainable trajectories (Kates et al. 2001). This is done to help design better approaches to sustainable management (i.e. ones that do not hinder meeting the needs of future generations), and adopting a holistic perception that considers different time periods and geographical areas with different environmental conditions. Working towards sustainability as an adaptive strategy, involves risks and opportunities; it is an interactive process with cumulative experiences (Kates 2000). In agreement with Costanza et al. (2007), only linking human and environmental change in the development, we can understand the complex web of causation across spatial and temporal scales, to develop an integrated understanding of the relation humanenvironment. The analysis we present here, is a proposition to integrate the temporal dimension in the management of allspice. The present study aims at integrating experiences over time and under various conditions, from history and present days, to provide a better understanding of the elements that contributed to the resurgence of allspice from being a marginalized crop to one prized worldwide.

\section{METHODS}

3 Document research was done in three specialized archives: The General Archives of the Indies (Archivo General de Indias - AGI) in Seville city, Spain; the National Historical Archives (Archivo Histórico Nacional - AHN) in Madrid, Spain; and the General Archives of the Nation (Archivo General de la Nación - AGN) in Mexico City, Mexico. In order to know details of harvest traditional technics and local commercialization, fieldwork research was conducted in Guatemala -at the heart of its natural distribution area, meaning from south of Mexico to Panama-, in summer 2018, applying a participatory ethnobotany approach to describing traditional management of allspice. The field study site was San Miguel Sechochoc, Raxruhá, in Alta Verapaz Department, Guatemala $\left(15^{\circ} 52^{\prime} 00^{\prime \prime} \mathrm{N} ; 90^{\circ} 02^{\prime} 39^{\prime \prime} \mathrm{W}\right)$, located $115 \mathrm{~km}$ from Cobán, the department capital (see map 1), and seated at $150 \mathrm{~m}$ asl, with $22.5^{\circ} \mathrm{C}$ annual average and $2100 \mathrm{~mm}$ as annual precipitation, where the predominant vegetation is tropical rain forest. Sechochoc is a very small and isolated town, where most of its population of around 1,000 participate in the harvest, the empirical management and the sale of allspice fruit and seeds. Therefore, they maintain the traditional practices inherited by generations, hence the importance of studying this particular place. With prior agreement from local authorities and following the compromise for an ethical study, data was collected on local allspice management and marketing methods. We used the information collected as a contrast to the large-scale production and marketing implemented in Mexico, the leading exporter of allspice in its native distribution area. 
Figure 1 : Localization of San Miguel Sechochoc, Raxruhá, Alta Verapaz (Guatemala)

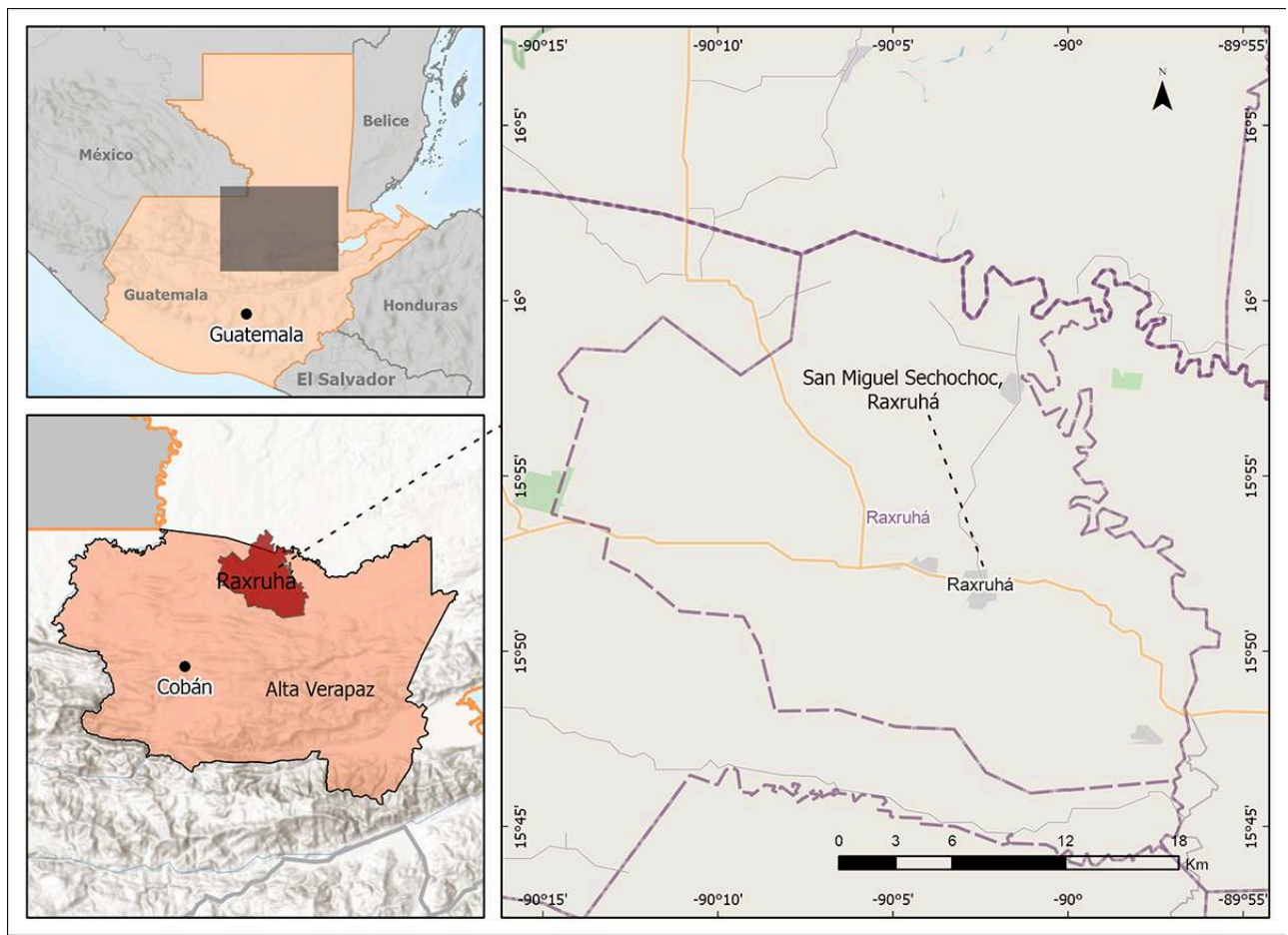

Elaborated by P. Machuca (LADIPA-El Colegio de Michoacán).

\section{RESULTS}

Belonging to the family Myrtaceae, the genus Pimenta includes two species grown as a spice ( $P$. dioica and $P$. racemosa); the currently accepted scientific name for both is Pimenta dioica (Merrill 1947). Allspice ( $P$. dioica) is an evergreen tree native to Mesoamerica where it can be found in humid tropical forests from southern Mexico and the southern Yucatan Peninsula to Guatemala, Honduras and even Costa Rica, as well as on the islands of Cuba and Jamaica. It is a midcanopy element in tropical rainforest and evergreen tropical forest where it forms mixed communities with other trees such as "canxán" (Terminalia amazonia (J.F. Gmel.) Exell), "ramón" (Brosimum alicastrum Sw.) and "guapaque" (Dialium guianense (Aubl.) Sandwith). It is ecologically important due to its abundance and height, which averages seven to ten meters but can reach as high as twenty meters (Figure 2) (Pennington \& Sarukhán 2005). The fruit is food for some birds (Cyanocorax morio, Melanerpes aurifrons, Saltator coerulescens, Thraupis abbas) and monkeys (Allouatta pigra) (Cancino-Oviedo 2017). 
Figure 2 : Allspice harvest as part of management and sale in Sechochoc, Guatemala

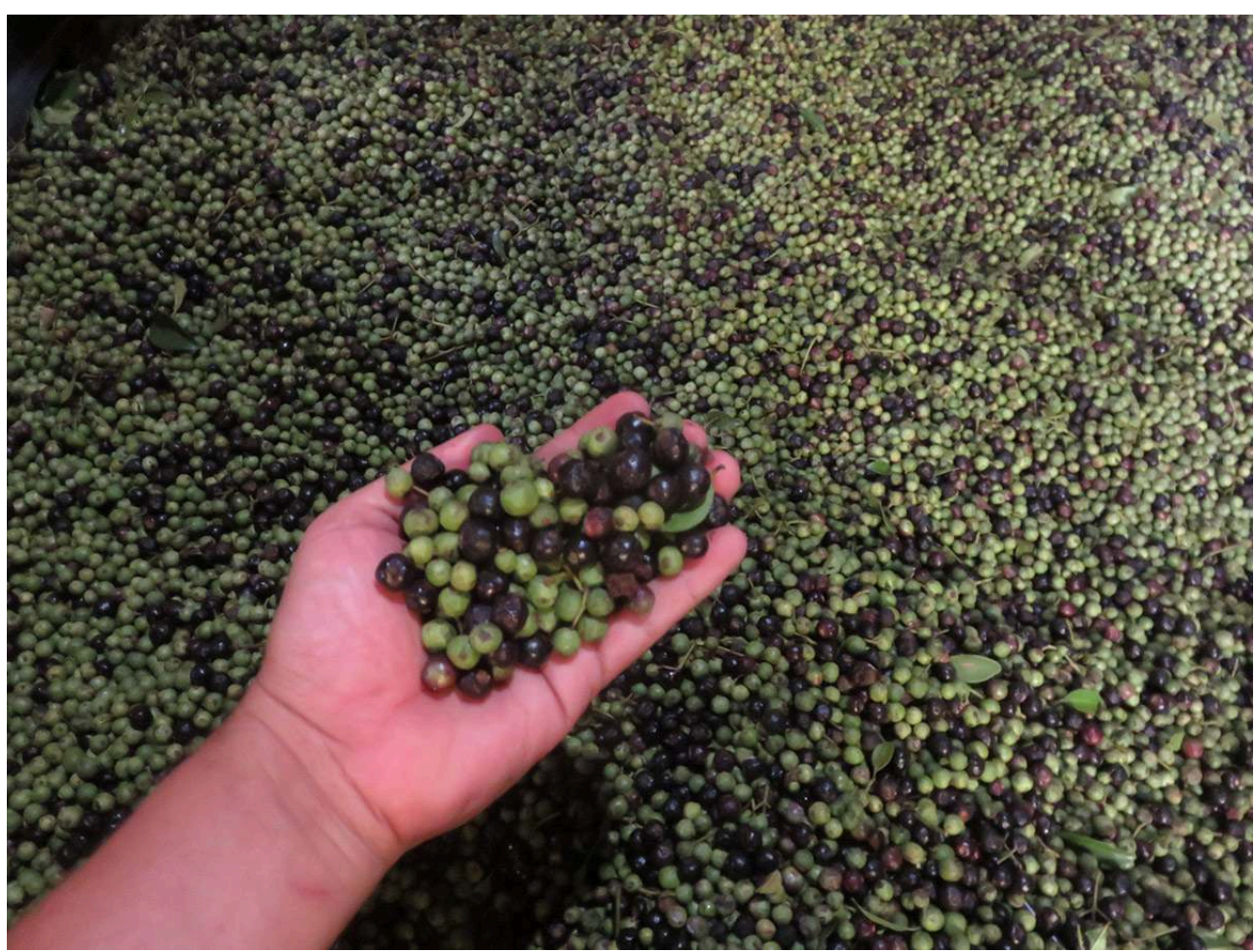

(c) F. Trabanino, July 2018

5 Allspice flowers are white and hermaphroditic (i.e. containing anthers and pistil), although in some cases flowers function as females and others as males. Male flowers contain about 100 anthers which produce fertile pollen, while female flowers contain about 50 anthers that produce infertile pollen but do form fruit (Chapman 1965). The allspice fruit is a berry containing two aromatic seeds. The tree bark is smooth and dry, and the wood is very hard and white-gray in color.

\section{The New World and the "discovery" of allspice}

6 Beginning in the 15th Century, one of the drives behind European expansion was the search for and control of the spice trade from Asia. Spices functioned both as culinary seasonings and medicines, with a commensurate demand in Europe and a broad interest in supplying that market. Thanks to trade routes with the East, Asian spices were known in Europe since ancient times. For centuries Arab peoples had taken a leading role in the spice trade between East and West, but in the early 16th Century they were displaced by the Portuguese and, later, by the Dutch and English (Machuca 2019).

7 In a quest to dominate direct trade of spices from Southeast Asia the Spanish used the Philippines as a base to develop the Manila-Acapulco trade axis. As an alternative they devised projects to acclimatize Asian spice species to New World climates; for instance, beginning in 1567 Guido de Lavezares sent ginger from the Philippines to New Spain and Hispaniola. Likewise, in 1584 Juan Bautista Román, controller and inspector for the Royal Treasury of the Philippines, suggested to King Philip II of Spain that Asian pepper (Piper nigrum) be introduced to the Americas to reduce the financial and human costs of 
the transpacific route (Machuca 2016). Bautista Román's proposal highlights the importance attributed to $P$. nigrum at this time. In this atmosphere of great expectations, in 1583 a royal certificate was addressed to the Audiencia of Santo Domingo notifying them that a settlement and contract had been granted Juan de Oribe to cultivate: [“... where best seems fit, pepper and allspice and Mení pepper and clove and cinnamon and ginger and nutmeg and sandalwood and lacquer, menguy and indigo and águila"]. The authorities on the island of Hispaniola were requested to grant the necessary lands to Oribe so that he could ["breed said spice selection"]. This same document also requested that the governor of Cuba, the mayors of Puerto Rico and the judges on Tierra Firme be notified that they should collaborate with whatever was necessary. ${ }^{1}$

8 However, this desire to convert the Americas into a cornucopia of the world's spices ultimately failed. Therefore, as Spanish colonization advanced the colonizers began to pay more attention to native spices such as allspice.

9 The first formal description of allspice was written by Francisco Hernández, Philip II's head physician, who conducted extensive research into the plants of New Spain between 1571 and 1576. Initially it was known by the Nahuatl name xocoxochitl or as Pipere Tavasci:

[Xocoxochitl, meaning sour flower, is a large tree, with leaves like those of the oranges, red flowers like a pomegranate, but with an aroma like the orange blossom, and in such a smooth and pleasant way, that even the leaves of the tree add to its attraction: the fruit is round, and hangs in clusters, which at first appear green, and then beige, and finally towards black: it is sharp and scathing to taste, and good-smelling (Hernández 1790: 336 ). ${ }^{2}$

10 Although P. dioica was known by the Spanish from early on there are few historical records of its production and trade. During the 17th Century and the first half of the 18th Century, Asian spices dominated the Spanish-American and European markets. It was not until the Bourbon reforms, in the 18th Century, when the Spanish began to consider some products from the Americas with economic potential, including allspice.

\section{Resurgence of Allspice in the 18th Century}

11 As the Bourbon reforms swept across the domains of the Spanish monarchy in the second half of the 18th Century, four developments occurred linked to allspice: its scientific study; its commercial development in southern New Spain; increased export to the Iberian Peninsula; and a project to acclimatize it in regions of Andalusia. By the 18th Century allspice was known by various names, resulting in its confusion with other pepper-like spices: in Spain and Latin America it was known variously as malagueta, pimienta de Tabasco, pimienta de Chiapa, pimienta americana and pimienta de la Jamaica. In Aragon and Catalonia it was called clavileña, in reference to clove (clavo in Spanish) (Gómez-Ortega 1780: 21). The English on Barbados called it allspice, and so it was known in England and Northern Europe. At the time Hans Sloane (1753: 464) explained its moniker as being in response to its having an aroma and taste redolent of a mixture of clove, juniper, cinnamon and pepper; he also states that it was the English who introduced allspice to the Flemish doctor and pioneering botanist Carolus Clusius. 


\section{Confusion in popular nomenclatura}

Clusius recorded allspice as Garyophyllon of Pliny (Ibid). In the apothecaries of Europe, allspice was registered under various scientific names, such as Piper caryophyllatum, Piper jamaycense, Pimenta, Amomum plinii, Piper chiapae, Piper tavasci, and Caryophyllon plinii. The French came to know it as English pepper, crowned pepper, Thevet pepper, amomi, aromatic coca of the Indies and clove head.

Allspice became confused with cardamom grown in India (Elettaria cardamomum (L.) Maton), or so-called grains of paradise (Aframomum melegueta (Roscoe) K. Schum.) of the Zingiberaceae family, and/or Piper guineense (Schumach. \& Thonn.) of the Piperaceae family. All were produced in western Africa and were also called (among other names) malagueta. African malagueta was also known as amomo, and has a flavor similar to that of Asian pepper. Indeed, on 20 July 1770, Fray Martín Sarmiento, a scholar of Galician culture, published a "Discourse on Malagueta" (Discurso sobre la Malagueta) in which he stated how difficult it was to identify the different species of peppers and chilis that abounded under the generic name "malagueta:"

["... the generic name given to it is Malagueta and Melegueta. It is brought from America to Spain, from Puerto Rico, I doubt that the vegetable brought from the Americas is specifically Malagueta; this originates and is abundant on the coasts of Guinea and [in]the country of the blacks, who use it for their stews and [as a] substitute for the oriental or Calecut pepper. So far [I] have not found an author who says that Malagueta originates in the Americas even if they use the name. Everything indicates that the word malagueta means western pepper; after all it is a spicy and hot vegetable and undoubtedly many vegetables that are hot like pepper come from Spanish America"] (Fray Martín Sarmiento 1770)3.

In Table 1 we summarize the species and popular names of the so-called "pimiento" worldwide. In all at least ten species from three botanical families (Myrtaceae, Piperaceae and Zingiberaceae) and four genera (Pimenta, Piper, Cubeba, Aframomum), none related to the other, overlap with allspice in terms of common names (Table 1). However, all do coincide in having spherical fruit with a strong aroma and somewhat spicy flavor.

In Mexico there are myriad local names for P. dioica: "moki" (Zoque, Chiapas); "detedan” (Cuicateco, Oaxaca); “malagueta," “papalolote” (Oaxaca); “u'ucum” (Totonaco, Veracruz);

"xocoxochitl" (Nahuatl) (Pennington \& Sarukhán 2005); and "nukuch pool" (Peninsular Maya) (Peña-Chocarro \& Knapp 2011). In Guatemala there are two ethnotaxa classifications for this species: "pens" (Quekchí) in Raxruhá, Alta Verapaz; and "ix nabakuk" "nab'aku'uk" (Itzá Maya) in Petén (Atran et al. 1993; Trabanino 2018). In Belize, as in the rest of the English-speaking world, it is known as "allspice." 
Table 1: Scientific and common names and natural distribution of allspice and other peppers historically confused with it

\begin{tabular}{|c|c|c|}
\hline SCIENTIFIC NAME & COMMON NAMES & NATURAL DISTRIBUTION \\
\hline \multicolumn{3}{|l|}{ MYRTACEAE } \\
\hline Pimenta dioica (L.) Merr. & $\begin{array}{l}\text { Pimienta Tabasco; malagueta; pimienta gorda; } \\
\text { pimienta de Jamaica; allspice. }\end{array}$ & $\begin{array}{l}\text { Mexico, Gulf slope and Yucatán Peninsula; } \\
\text { Central America and the Antilles. }\end{array}$ \\
\hline Pimenta racemosa (Mill.) J.W. Moore & Malagueta; Bay rum & The Antilles \\
\hline Pimenta racemosa var. ozua (Urb. \& Ekman ) Landr. & Fey esans & Endemic to Hispaniola (Santo Domingo) \\
\hline \multicolumn{3}{|l|}{ PIPERACEAE } \\
\hline Piper nigrum L. & Pimienta negra, black pepper & Asia \\
\hline Piper retrofractum Vahl. & Pimienta de Java, Javanese long pepper & Indonesia \\
\hline Piper longum $\mathrm{L}$. & Pimienta larga, Indian long pepper & India \\
\hline Cubeba officinalis Raf. & Cubeba & Java, Maluku Islands, Africa, Asia \\
\hline Piper betel Blanco & Betel & India, Malaysia and the Philippines \\
\hline Piper guineense Schumach. \& Thonn. & Pimienta de Guinea, Guinea pepper & Central and western Africa \\
\hline \multicolumn{3}{|l|}{ ZINGIBERACEAE } \\
\hline Aframomum melegueta (Roscoe) K. Schum. & Melegueta; cardamom & West Africa \\
\hline
\end{tabular}

Source: Bailey 1951; Geilfus 1994; Germosén-Robineau 2014; Gundala \& Aneja 2014; 1994; León 1987; Pennington \& Sarukhán 2005; Tropicos, 2019.

\section{Recorded uses in New Spain}

17 Allspice received periodic attention in the chronicles of early colonizers and was occasionally studied in Europe. Perhaps the earliest mention is that of Fray Diego de Landa (1524-1579) in his book "Relation of the Things of Yucatan" (Relación de las cosas de Yucatán). He mentions that [“...they toast the corn, grind it and mix in water which is a very refreshing drink, they throw in some Indian pepper or cocoa"] (Landa 1979). The drink he describes, "pozol," is still commonly drunk both daily and during ceremonies by peasants in Mexico's humid tropical regions (personal experience; Rodríguez-Yc 2013). Hans Sloane (1753) mentions that, apothecaries in England would use allspice in the absence of carpo balsam, and indeed preferred it because it was more fragrant and aromatic, and less astringent and balsamic.

18 In 1780 Casimiro Gómez-Ortega, professor at the Madrid Botanical Garden, published the "Natural History of Malagueta or Tabasco Pepper" in which he states that P. dioica has the same nutritional and medicinal uses as other eastern spices such as black pepper, cloves and cinnamon. He compared the spicy aroma of allspice to that of black pepper, cinnamon and cloves, but recognized that, even though its flavor was similar to oriental pepper, it was ["incomparably finer"]. Using a description made by Hans Sloane in 1686, Gómez-Ortega stated that pimento de Jamaica and malagueta were very similar but with variations in color, possibly be due to the different soils and climates in which they grew. Gómez-Ortega also provided citations for allspice's putative medicinal uses. He cites the royal head physician Francisco Hernández: [“...It is very effective for lifting the spirits, fortifying the head and stomach, for clearing and attenuating thick and viscous humors, for dissipating flatus, facilitating the evacuation of urine and menstruation, and stimulating the appetite; and in a word, for the same uses that the most precious oriental spices are used"] (Gómez-Ortega 1780: 22).

In the 17th century, Francisco de Uría took allspice to Spain, where Dr. Francisco Redi carried out several experiments, observing its effect against epilepsy and severe gout: 

possible to find new practices; it is now when we leave the past and move into the present. For example, allspice has at least nine reported uses in its original distribution area (Argueta \& Cano 1994; Martínez-Pérez et al. 2013): essential oil as flavoring; tea leaves; fruit as a condiment; wood for construction, tools and as fuel; essence for cosmetics, and as an insecticide and medicinal. Chewing green raw leaf relieves toothaches and is also used in some communities as a tea to relieve stomach pain; against dysentery and cough; to hasten birth and stop menstruation. Allspice oil has 
antifungal activity. The wood is so hard as to be difficult to work but is used in handicrafts. The trunk of the tree is useful for house construction and the branches can be used as handles for some tools. In gastronomy it holds a privileged place for its delicate flavor that combines clove, cinnamon, black pepper and nutmeg; it is used in sauces.

\section{Current cultivation}

The historical background presented above allows us to delve into current cultivation practices. Allspice grows in warm-humid climates with year-round rains, and warmsubhumid climates with summer rains, average temperatures ranging from 22 to $29^{\circ} \mathrm{C}$ (no higher) and annual rainfall from 1,000 to 2,500 mm (Benítez et al. 2004). It grows best at 0 to $300 \mathrm{~m}$ asl, but can grow at up to $500 \mathrm{~m}$ asl, and does not tolerate temperatures higher than $29^{\circ} \mathrm{C}$ or winds greater than $90 \mathrm{~km} / \mathrm{h}$ (Monroy-Rivera 2011). On the Yucatan Peninsula these climate conditions are only met in the south (MartínezPérez et al. 2013).

Allspice forms part of home gardens in south and southeast Mexico, and part of forest management systems in El Petén and Alta Verapaz in Guatemala (Mariaca 2012: 51; Ordóñez-Díaz 2018). It is planted near dwellings (Figure 3), but also frequently in plantations outside of town, next to rows of "pineapple" and fruit trees such as "mamey" (Pouteria sapota (Jacq.) H.E. Moore \& Stearn), "nance" (Byrsonima crassifolia (L.) Kunth, "avocado" (Persea americana Mill.), "guava" (Psidium guajava L.), "oranges" (Citrus spp.), "cardamom" (Elettaria cardamomum (L.) Maton), "vanilla" (Vanilla planifolia Andrews), "cocoa" (Theobroma cacao L.), "balam" (Theobroma bicolor Bonpl.) and "coffee" (Coffea arabica L.). 
Figure 3 : Allspice trees in orchard in Sechochoc, Guatemala

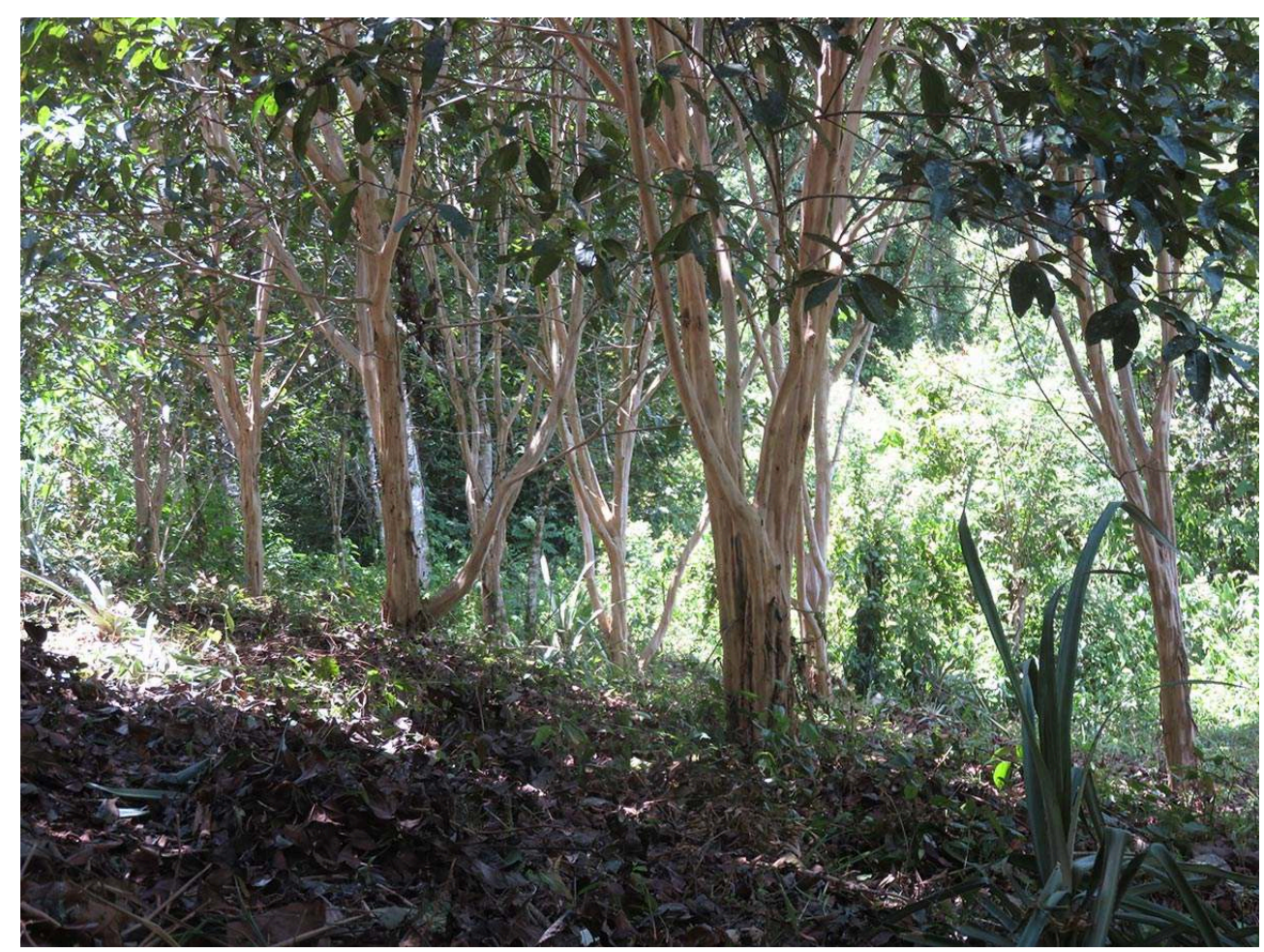

(C) F. Trabanino, July 2018

Due to its distinctive flavor it has become popular in other parts of the world, including India. Here it is one of the main spices grown alongside major commercial crops such as "chili peppers" (Capsicum annuum L. and Capsicum frutescens L.), "black pepper" (Piper nigrum L.) and "long pepper" (Piper longum L.). In India demand was such that it was imported from Malaysia and Singapore where it has been successfully grown for use as a flavoring in foods and wines (Ilyas 1976).

In some populations of Guatemala, allspice is grown following traditional methods (Figure 4). In these cases, it is harvested during the rainy season in July alongside "nance" (B. crassifolia) avocado (P. americana), "breadfruit" (Artocarpus altilis (Parkinson) Fosberg), "lemon" (Citrus limon (L.) Osbeck) and "breadnut," "ramon" (Brosimum alicastrum Sw.). To harvest allspice, pickers climb into the tree canopy (approx. $6 \mathrm{~m}$ ), and while sitting on a wooden board and collect fruit clusters (including stems and leaves) in a sack. Harvesting often requires several continuous hours in tree canopies. Once on the ground the individual fruits are detached, often by children. 
Figure 4 : Traditional drying of allspice fruit in orchard after collection

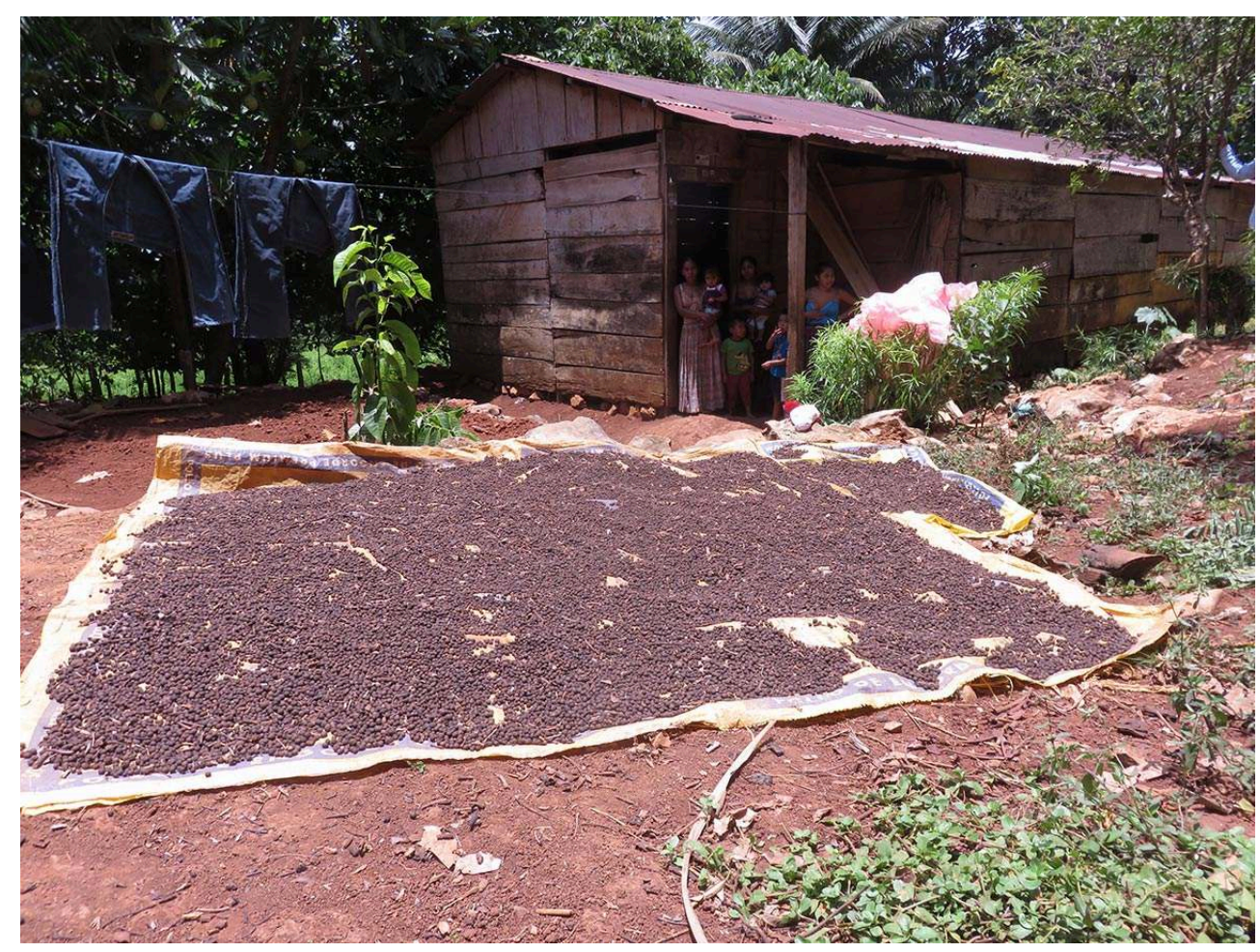

(c) F. Trabanino, July 2018

31 Another harvesting technique is to collect fruit that has dried on the tree and fallen. This is done on large plantations with trees planted 5 meters apart. Fallen leaves and fruit are swept up and placed in baskets, and the dried leaves discarded, leaving only the fruit. This is done by whole families including children and women, even with nursing babies. The fresh fruit can be sold as is or sun-dried, which brings a higher price.

In the Sierra Norte mountains of the state of Puebla, Mexico, germinated wild allspice seedlings are obtained from seeds deposited in bird excrement. Local people have observed that rounded fruit and seeds produce male trees while irregularly-shaped fruit containing two seeds produce females. They also mention that it requires no fertilizer and that pruning promotes production of a larger number of branches. Fruit are harvested during August and September by carefully placing crossbars in the tree canopy to collect fruit clusters. In this region seven people were reported to have collected $22.5 \mathrm{~kg}$ in 70 minutes (Macía 1998).

Due to allspice's economic importance a manual was prepared by the Mexican government detailing its cultivation (Monroy-Rivera 2011). This covers the entire process of land and soil preparation through cultivation, pruning, pest control, production and harvest.

\section{Current Market}

34 Jamaica is currently the largest exporter of allspice, with $70 \%$, in an international trade that reports from 3000 to $4000 \mathrm{t}$. The other exporting countries are Mexico, Honduras, Guatemala, Brazil and Belize, while the main importers are the United States, the 
United Kingdom, Germany, the Scandinavian countries and Canada (Chauvet 2019: 489). Mexico is the largest allspice exporter in Mesoamerica and poses serious competition for other producing countries. In Mexico, Veracruz accounts for $56.9 \%$ of the area sown in allspice, Tabasco contributes $29.8 \%$, Chiapas $10.7 \%$, Puebla $2.3 \%$ and Oaxaca $0.4 \%$ (Martínez-Pérez et al. 2013). Current price for allspice as a food seasoning ranges from $\$ 155.00$ to $\$ 540.00$ pesos (MX) / kilo (approx. \$7.7 to \$27.0 USD).

In southern Veracruz, harvest is reported to occur from trees in the jungle, which grow at a density of approximately two trees per hectare. Payment for harvest is agreed upon between pickers and an intermediary during the flowering stage; the pickers receive $\$ 1.00 \mathrm{MX} / \mathrm{Kg}$. (\$0.052 USD). When trees are grown in backyards they are harvested by the owners. These informal conditions suffer from a lack of effective community organization that would help to achieve the expected benefits and/or consolidate its continuous use (Hernández-Prieto \& Ricker 2009).

In Chiapas, the work of the Jotiquetz Pepper Cooperative Society (Sociedad Cooperativa Pimienta Jotiquetz), run by a local organization called Moki (which means Pepper in the Zoque language), has made allspice an example of agricultural success in Mexico (Reyes-Martínez 2017). After consolidating sustained production using innovations in various links of the production chain, including certification for organic production, this cooperative now exports allspice.

37 A notable success story is the company Asociaciones Agroindustriales Serranas S.A. de C.V. Founded in 1994, it has implemented a series of production and marketing innovations and currently exports agricultural products to over thirty countries on four continents. The company primarily distributes three commercially important crops: cocoa, coffee and allspice. Its produces allspice in states of Veracruz, Puebla and Tabasco. This company has managed to articulate production with the market and has been the main allspice exporter in Mexico for the past twenty years (Córdoba-Carballo 2017). In 2018, it was awarded the Latin American award from the Global Food Safety Conference for being an exemplary company in world markets.

In Raxruhá, Guatemala, sacks of green allspice are carried out to be sold in the farmer's markets of Alta Verapaz on Wednesdays. Small producers find it challenging to transport the product out of the forest and cannot directly access international markets, so they use trucks that visit rural areas to transport agricultural products to market. Producers in remote villages often sell allspice to intermediaries who transport it to Guatemala City and from there it is exported.

Both Honduras and Costa Rica also produce allspice. Production in Honduras fluctuates depending on when trees produce fruit. However, exports have improved since 2012, when a cooperative of organized producers emerged to take advantage of a potential market in the United States (Ministry of Agriculture and Livestock 2014).

\section{DISCUSSION}

Because of the similarity of allspice's "spicy" flavor to that of black pepper (pimiento in Spanish) it was known as pimienta gorda or pimiento de Tabasco, understandably leading to some confusion. Another confusing factor during the first five hundred years of allspice trade was its visual similarity to the Asian peppers already known in Europe during the 15th, 16th and 17th centuries. However, beginning in the 17th Century 
allspice's distinctive flavor characteristics opened markets, consequently encouraging its trade and cultivation. After its establishment as a standard trade good in the late 18th Century it has been in demand up to the present.

Our results go in agreement with Macía (1998) in the sense that allspice is still appreciated and harvested in small rural communities throughout its natural range, but has also been developed into a commercial export product. Its permanence in these rural areas is based on its local medicinal uses and sale of the fruit collected by family groups. There are different environmental and cultural characteristics throughout southern Mexico to Guatemala and the other countries where allspice grows naturally, but at the rural level there are aspects (e.g. the presence of natural vegetation) that stand out in the history of this shared plant species. Exploitation at this level follows the natural cycle of the allspice tree, with harvest occurring when fruit are present with sale soon thereafter, such as in Guatemala and Honduras. Our findings in Sechochoc, Raxruhá, are according with Gillespie et al. (1993) even 25 years after that study, which reinforce the arguments of usefulness and valuable commodity.

In contrast large-scale cultivation and marketing systems have been developed in Mexico, allowing producers to dominate the regional export market. The most outstanding example is Asociaciones Agroindustriales Serranas, which diversified allspice production with coffee and cocoa (Córdoba-Carballo 2017). Due to constant demand, allspice is their main income source, which allows the company to weather market vicissitudes in their other commodities. This and other companies have improved post-harvest processes to ensure that allspice is available and exportable year-round. They have also innovated in terms of their internal organization and by establishing mutually beneficial contracts with producers.

43 The history of the post-Contact allspice trade is like that of other native species in Mesoamerica that were marginalized by the colonizing culture (León 1992). This was part of the cultural domination process in which the colonized seemed unable to highlight the advantages offered by many native species. Organization of producers in allspice's native distribution was crucial to strengthening its image and maintaining or increasing cultivated area. However, historical analysis shows that government policies were also vital to positioning products from the colonies in national and international markets.

The transition of allspice from a marginalized crop to one that has an ongoing international market can function as an example of sustainable management in the sense of Kates et al. (2001). Is a successful long experience that could be useful to apply for other unknown or under-utilized native plant species that have been employed by humans but have no current formal markets.

Designing any sustainability strategy for future in the sense proposed by Costanza et al. (2007), requires biological information about myriad plant and animal species, and on specific regional conditions, both ecological and social, in different times as a critic path, considering different conditions to emerge different ways of management for different natural resources. Applying a holistic vision of a resource, that includes its history vis-à-vis humans, as we presented here for allspice, contributes to its sustainable and permanent management into the wild as an important part of the local biodiversity and to monetizing it within a fair-trade scenario.

Acknowledgements 
The authors thank the producers of Sechochoc, Raxruhá, Guatemala, for sharing their experiences with allspice. Thanks are also due to Dr. Chloé Andrieu (Director, Old Raxruhá Archaeological Project, Université Paris 1-Panthéon-Sorbonne, CNRS UMR 8096, Archéologie des Amériques), for the opportunity and support to stay in Sechochoc doing archaeological field work. Thanks to the evaluators for their valuable comments that allowed us to improve the article. Also thanks to Dr. Thomas Calvo (El Colegio de Michoacán) as a reviewer for the abstract in French.

\section{BIBLIOGRAPHY}

AGI. Archivo General de Indias. Sevilla, España. Consulted on May, 2018.

AGN. Archivo General de la Nación. Mexico City. Consulted on 2017.

AHN. Archivo Histórico Nacional. Madrid, España. Consulted on May, 2018.

Argueta A. \& Cano L. (Ed.) 1994 - Atlas de la Medicina Tradicional Mexicana. México, Instituto Nacional Indigenista, Vol II. : 1154-1155.

Atran S. et al. 1993 - Itza Maya Tropical Agro-Forestry. Current Anthropology $34: 633-700$. [Online] URL: http://doi.org/10.1086/244212

Bailey L.H. 1951 - Manual of Cultivated Plants. New York, McMillan Publ. Co., 1116 p.

Benítez G., Pulido-Salas M.T. \& Equihua M. 2004 - Árboles Multiusos Nativos de Veracruz para Reforestación, Restauración y Plantaciones. México, Instituto de Ecología and Comisión Nacional Forestal, $288 \mathrm{p}$.

Cancino-Oviedo L. 2017 - Diásporas consumidas o dispersadas por aves y mamíferos de la Península de Yucatán. Thesis, Biology. Universidad Autónoma de Yucatán. México, Mérida, 129 p.

Chapman C.P. 1965 - A new development in the agronomy of pimento. Caribbean Quarterly 10 : 3-9. [Online] URL: https://doi.org/10.1080/00086495.1965.11828912. (Accessed 19 Agosto 2019).

Chauvet M. 2019 - Encyclopédie des plantes alimentaires. Paris, Belin : 488-489.

Córdoba-Carballo P. 2017 - Pimienta y mercado diferenciado, 40 casos de éxito. México, Secretaría de Agricultura, Pesca y Alimentación and Asociaciones Agroindustriales Serranas, 31 p. [Online] URL: https://www.redinnovagro.in/casosexito/2017/Pimienta_Asociaciones_A_Serranas.pdf

Costanza R., Graumlich L., Stephen W., Crumley C., Dearing J., Hibbard K., Leemans R., Redman Ch., Schimel D. 2007 - Sustainability of collapse: What can we learn from integrating the history of humans and the rest of nature? Ambio 36 (7) : 522-527. [Online] https://bioone.org/journals/ AMBIO (Accessed March 28, 2020).

Davidse G., Souza M. y Knapp S. 2011 - Flora Mesoamericana, general information. Missouri Botanical Garden. [Online] URL: http://www.mobot.org/MOBOT/FM/geninfo.html\#general. (Accessed 11 September 2019).

Geilfus F. 1994 - El Árbol al Servicio del Agricultor. Vol. 2. CATIE Costa Rica. 804 p. (Manual Técnico ; 9). 
Germosén-Robineau L. (Ed.) 2014 - Farmacopea Vegetal Caribeña. Centro de Investigación Científica de Yucatán. México : 297-303.

Gillespie A.R., Knudson D.M. \& Geilfus F. 1993 - The structure of four home gardens in the Petén, Guatemala. Agroforestry Systems 24 : 157-170. [Online] URL: https://doi.org/10.1007/BF00706889

Gómez-Ortega C. 1780 - Historia Natural de la Malagueta o Pimienta de Tabasco, y noticia de los usos y virtudes. Madrid, Imprenta de Cámara de su Majestad por Joaquín Ibarra : 11-23.

González-de Cosío M. 1984 - Especies Vegetales de Importancia Económica en México. Porrúa. México, $315 \mathrm{p}$.

Gundala S.R. \& Aneja R. 2014 - Piper betel /leaf: A reservoir of potential xenohormetic nutraceuticals with cancer-fighting properties. American Association for Cancer Research. [Online] URL: https://cancerpreventionresearch.aacrjournals.org/content/canprevres/7/5/477.full.pdf https://doi: 10.1158/1940-6207. CAPR-13-0355. (Accessed 12 August 2019).

Hernández F. 1790 - Hernandi Francisci, Medici atque historici Philippi II Hisp. Et Indiar, regis, et totius novi orbis archiatri, opera edita, tum inédita, ad autographi fidem et integritatem expressa, vol. 3. Imprenta de los Herederos de Ibarra. Madrid.

Hernández-Prieto L.A. \& Ricker M. 2009 - Economical valuation of Allspice (Pimenta dioica) production for the restoration strategies proposed for the recovering of "Los Tuxtlas" livestock pastures (Veracruz, Mexico). [Online] URL: https://www.doc-developpement-durable.org/file/ Culture-epices/piment-de-la Jamaique/ Economical\%20valuation\%20of\%20Allspice\%20Pimenta\%20dioica_Mexico.pdf (Accessed November 2019).

Ilyas M. 1976 - Spices in India. Economic Botany 30 : 273-280. [Online] URL: https://doi.org/ 10.1007/BF02909735 (Accessed March 2019).

Kates R.W. 2000 - Cautionary tales: Adaptation and the global poor. Climatic Change 45 : 5-17. [Online] URL: https://doi.org/10.1023/A:1005672413880 (Accessed December 2019).

Kates R.W, Clark W.C., Corell R., Hall J.M., Jaeger C.C., Lowe I., McCarthy J.J., Schellnhuber H.J., Bolin B., Dickson N.M., Faucheux S., Gallopin G.C., Grübler A., Huntley B., Jäger J., Johda N.S., Kasperson R.E., Mabogunje A., Matson P., Mooney H., Moore B.III, O’Riordan T. \& Svedin U. 2001 Sustainability science. Science 292 (5517) : 641-642. [Online] URL: https://doi: 10.1126/science. 1059386

Landa D. 1979 - Relación de las cosas de Yucatán. México, Ed. Porrúa, 252 p.

León J. 1987 - Botánica de los Cultivos Tropicales. Instituto Interamericano de Cooperación para la Agricultura. San José, Costa Rica, 445 p.

León J. 1992 - Plantas domesticadas y cultivos marginados en Mesoamérica. In : HernándezBermejo J.E. \& León J. (Ed.) Cultivos marginados, otra perspectiva de 1492. FAO. Collection Plant Production and Protection $26: 37-44$.

Machuca P. 2016 - La palma de coco. Regalo de Filipinas a México. In : Calvo Th. \& Machuca P. (Ed.). México y Filipinas: Culturas y memorias sobre el Pacífico. El Colegio de Michoacán and Ateneo de Manila University Press : 321-340.

Machuca P. 2019 - Historia mínima de Filipinas. México, El Colegio de México : 61-73.

Macía M.J. 1998 - La pimienta de Jamaica (Pimenta dioica (L.) Merrill), Myrtaceae, en la Sierra Norte de Puebla (México). Anales del Jardín Botánico de Madrid 56 : 337-349. 
Mariaca R. 2012 - La complejidad del huerto familiar maya del sureste de México. In: Mariaca R. (Ed.) El huerto familiar del sureste de México. Secretaría de Recursos Naturales y Protección Ambiental de Tabasco and El Colegio de la Frontera Sur : 7-97.

Martínez-Pérez D. et al. 2013 - La Pimienta gorda en México (Pimenta dioica L. Merril), avances y retos en la gestión de la innovación. Universidad Autónoma Chapingo, 74 p. (Colección Trópico húmedo).

Merrill E.D. 1947 - The technical name of allspice. Contributions from the Gray Herbarium of Harvard University $165: 30-38$.

Ministry of Agriculture and livestock 2014 - Perfil de Mercado de la Pimienta Gorda Pimenta dioica (L.) Merrill. Programa Nacional de Desarrollo Agroalimentario. Honduras. [Online] URL: http:// bvirtual.infoagro.hn/xmlui/handle/123456789/227

Monroy-Rivera C.R. 2011 - Paquete tecnológico Pimienta gorda (Pimenta dioica L. Merril), establecimiento y mantenimiento. México, Instituto Nacional de Investigaciones Forestales, Agrícolas y Pecuarias, $14 \mathrm{p}$.

Ordóñez-Díaz M.J., Lope-Alzina D.G. \& Pulido-Salas M.T. 2018 - Estado actual de los huertos familiares en siete estados del sur y sureste de México. Chapter 10. In : Ordóñez-Díaz, M.J. (coord.). Atlas Biocultural de Huertos Familiares en México. Universidad Nacional Autónoma de México. México : 412.

Pennington, T.D. \& Sarukhán J. 2005 - Árboles Tropicales de México. $3^{a}$. ed. Instituto de Ecología, Universidad Nacional Autónoma de México. 521 pp.

Peña-Chocarro M. \& Knapp S. (Ed.) 2011 - Árboles del Mundo Maya. Natural History Museum, Protection to nature (PRONATURA, A.C.), Universidad Autónoma de Yucatán and Universidad Valle de Guatemala. México. 263 pp.

Reyes-Martínez A. 2017 - Chiapas exportando pimienta gorda. Sociedad Cooperativa Jotiquetz. Secretaría de Agricultura, Ganadería, Desarrollo Rural, Pesca y Alimentación. México. [Online] URL : https://www.redinnovagro.in/casosexito/2017/

Pimienta_Sociedad_Cooperativa_Pimienta_Jotiquetz.pdf (Accessed August 2019).

Rodríguez-Yc J.R. 2013 - La molienda en Mesoamérica, formas, funciones, usos y manufactura de los instrumentos. Tesis, Doctor en Historia. Universidad de Barcelona. Barcelona, Spain. 580 pp.

Sloane H. 1753 - A Description of the Pimienta or Jamaica Pepper-Tree, and of the Tree that bears the Cortex Winteranus. Proceedings of the Royal Society of London, Philosophical transactions. Pp: 462-468. [Online] URL: https://archive.org/details/philtrans09585620 doi: 10.1098/rstl.1686.0083

Trabanino F. 2018 - El Uso del cacao en Sechochoc. Informe de campo. Proyecto Arqueológico Raxruhá Viejo. Nanterre. Paris, Centre National de la Recherche Scientifique, $17 \mathrm{p}$.

Tropicos.org 2019 - Missouri Botanical Garden. Data base on line. http://www.tropicos.org/ Home.aspx. (Accessed August 2019).

\section{NOTES}

1. AGI, Santo Domingo, 868, L. 1, f. $152 \mathrm{v}-153$ r.

2. Original Spanish translated from the Latin by Casimiro Gómez-Ortega.

3. AHN, Diverse collections, 38, N.13, f.1.

4. AGN, Indiferente virreinal, caja 2547, exp. 40.

5. AGN, Consulado, vol. 172, exp. 22. 


\section{ABSTRACTS}

European expansion in the 16th Century produced a worldwide circulation of plants.

Spanish colonialism displaced native plant resources while also promoting a mixture of old and New World food cultures. That is the case of allspice, the fruit of the Pimenta dioica (L.) Merrill, a native tree to tropical forest in Mesoamerica that eventually became highly valued as a spice in global markets. For this study we trace the trade history of allspice and describe some common current traditional practices for harvest and commercial production strategies. Initially confused with other pepper-like spices, allspice was partially marginalized during the first two centuries of Spanish colonization, but later support from the Spanish Crown helped it to become actively traded beginning in the $18^{\text {th }}$ Century. In Guatemala, its region of natural distribution, allspice is still produced following traditional techniques and is commercialized in local markets, although there are well-established large-scale producers in Mexico that export it. The present study aims at integrating experiences over time and under various conditions, from history and present days, to provide a better understanding of the elements that contributed to the resurgence of allspice from being a marginalized crop to one prized worldwide. We conclude that allspice survived the vicissitudes of colonialization partially due to government intervention, and eventually became a valuable commodity, even in our days.

L'expansion européenne au $\mathrm{XVI}^{\mathrm{e}}$ siècle a produit une circulation mondiale des plantes. La colonisation espagnole a déplacé les ressources végétales indigènes tout en favorisant un mélange de cultures alimentaires de l'Ancien et du Nouveau Monde. C'est le cas du piment de Jamaïque, fruit de l'arbre Pimenta dioica (L.) Merrill, originaire des forêts tropicales de Mésoamérique, qui est finalement devenu très apprécié comme épice dans le marché global. Dans cet article nous retraçons son histoire commerciale et décrivons les stratégies de production traditionnelles et commerciales actuelles. Initialement confondu avec d'autres épices ressemblant au poivre, le piment de Jamaïque a été partiellement marginalisé pendant les deux premiers siècles de la colonisation espagnole. Le soutien de la Couronne espagnole l'a aidé à être activement commercialisé à partir du XVIII ${ }^{\mathrm{e}}$ siècle. Au Guatemala, sa région de distribution naturelle, le piment de Jamaïque est toujours cultivé selon des techniques traditionnelles pour la vente sur les marchés locaux, bien qu'il existe au Mexique de grands producteurs bien établis qui l'exportent. Notre étude vise à intégrer des expériences au fil du temps et dans diverses conditions, du passé à nos jours, pour contribuer à une meilleure compréhension des éléments qui ont contribué à la résurgence du piment de Jamaïque, passant d'une culture marginalisée à une autre mondialement appréciée. Nous concluons que cette épice a survécu aux vicissitudes de la colonisation en partie grâce à l'intervention du gouvernement, et est finalement devenue une denrée précieuse, même de nos jours.

La expansión europea del siglo XVI produjo una amplia circulación de plantas. El colonialismo español desplazó diversos recursos vegetales nativos, a la vez que favoreció la mezcla de culturas alimentarias entre el Viejo y el Nuevo Mundo. Ese es el caso de la pimienta de Tabasco, fruto del árbol de la Pimenta dioica (L.) Merrill, originaria de los bosques tropicales de Mesoamérica, la cual se convirtió en una especia muy apreciada con el paso del tiempo. En este artículo presentamos su trayectoria histórica, a la vez que describimos las estrategias tradicionales y comerciales actuales. Inicialmente confundida con otras especias similares a la pimienta asiática, la pimienta de Tabasco estuvo parcialmente marginalizada durante los dos primeros siglos de colonización española. Sin embargo, a partir del siglo XVIII, el impulso otorgado por la Corona española incentivó su comercio. En Guatemala, su región de distribución natural, la pimienta de Tabasco todavía se cultiva con técnicas tradicionales para la venta en mercados locales, al tiempo que en 
México existen grandes productores bien establecidos que la exportan. Nuestro estudio trata de integrar las experiencias a través del tiempo y en sus diversas condiciones, desde una perspectiva histórica y actual; así, logramos tener una mejor comprensión de los elementos que ayudaron a resurgir en el Siglo de las Luces, pasando de un cultivo marginal a otro de talla mundial. Concluimos que la pimienta de Tabasco sobrevivió pese a las vicisitudes de la colonización, en parte gracias al impulso que le dio la administración colonial tardía, lo que a la postre la convirtió en una especia altamente apreciada, incluso hasta nuestros días.

\section{INDEX}

Mots-clés: mondialisation, échange des plantes, piment de Jamaïque, durabilité, pratiques traditionnelles, cultures marginalisées

Keywords: globalization, exchange of plants, tabasco pepper, sustainability, traditional management, under-utilized crop

Palabras claves: globalización, intercambio de plantas, pimienta de tabasco, sostenibilidad, manejo tradicional, cultivos marginales

\section{AUTHORS}

\section{PAULINA MACHUCA}

Laboratorio de Análisis y Diagnóstico del Patrimonio (History), El Colegio de Michoacán, La Piedad, Michoacán, México

\section{MARÍA TERESA PULIDO-SALAS}

Banco de Germoplasma, Centro de Investigación Científica de Yucatán (Botany), Mérida, Yucatán, México - pulidosalas@gmail.com

\section{FELIPE TRABANINO}

Jardín Botánico, Universidad San Carlos de Guatemala (Botany), Guatemala. 